\title{
The Characterization of Airborne Occupational Safety and Health Hazards in Selected Small Businesses; Manufacturing Wood Pallets
}

\author{
Robert MALKIN ${ }^{*}$, Thomas J. LENTZ ${ }^{1}$, Jennifer TOPMILLER ${ }^{2}$, \\ Stephen D. HUDOCK ${ }^{2}$ and Richard W. NIEMEIER ${ }^{1}$ \\ ${ }^{1}$ National Institute for Occupational Safety and Health, Education and Information Division, USA \\ ${ }^{2}$ National Institute for Occupational Safety and Health, Division of Applied Research Technology, USA
}

Received August 31, 2005 and accepted November 24, 2005

\begin{abstract}
Researchers from the National Institute for Occupational Safety and Health (NIOSH) investigated occupational safety and health concerns in the small business wood pallet manufacturing industry because of an injury rate (2000) $226 \%$ greater than that for general industry ${ }^{1}$. NIOSH investigators conducted walk-through evaluations at seven wood pallet manufacturing companies, and returned to four of them to take environmental measurements. Carbon monoxide (CO) levels, noise levels, and total particulate were measured, ergonomic observations made, and occupational safety practices analyzed at each of the four facilities where measurements were taken. The focus of this study is the evaluation of airborne particulate and carbon monoxide exposures for the purpose of determining areas of potentially high exposures. This knowledge can guide the plant owner or health professional to determine whether further measurements are necessary and where they might be needed. Safety factors and physical stressors (noise and ergonomic stressors) were described in a previously published companion paper ${ }^{2}$. Although we did not take $8 \mathrm{~h}$ samples, we did find certain exposures that were potentially of concern to the small business owner. The main findings of this investigation were as follows: 1 ) $\mathrm{CO}$ levels in three plants, for the time periods measured, were less than the OSHA permissible exposure limit (PEL) of 50 parts per million (ppm) for an 8-h TWA. Three measurements, all from one plant, were due to a older and defective forklift and were above $50 \mathrm{ppm}$. 2) Total dust measures ranged from 0.86 to $1.67 \mathrm{mg} / \mathrm{m}^{3}$, taken adjacent to an operating machine cutting hardwood and measured up to $6 \mathrm{~min}$. The American Conference of Governmental Industrial Hygienists (ACGIH) guideline for hardwood dust is $1.0 \mathrm{mg} / \mathrm{m}^{3}$, again for an 8 -h TWA.
\end{abstract}

Key words: Pallets, Noise, Forklifts, Saws, Ventilation, Ergonomics, CO, Wood

\section{Introduction}

Of the approximately 6.9 million private industry establishments that were operating in the United States in 1998, more than 6.6 million (95\%) employed fewer than 50 employees and approximately 6.0 million (86\%) employed fewer than 20 employees $^{3)}$. Seventy two percent of all wood pallet and container manufacturing firms (North American Industry Classification System [NAICS] 32192) employed less than 20 workers $^{3)}$.

Prevention of occupational injury and illness, however, is often difficult for small business establishments because

*To whom correspondence should be addressed. they generally have few safety and health resources, do not hire staff devoted to safety and health activities, and often lack the ability to identify occupational hazards and conduct surveillance. Challenges to promoting occupational safety and health in small businesses include the variability of work settings, the receptiveness of the small business owner to government intervention, and the number of workers who can be reached at any one workplace or through an effective network ${ }^{4}$.

This investigation of the wood pallet manufacturing industry was prompted by its high rate of injury. Analysis of Bureau of Labor Statistics (BLS) data showed that the incidence rate (2000) for non-fatal injuries involving days away from work in the wood pallet and skid (SIC 2448) 
manufacturing industry was $226 \%$ greater than that for general industry ${ }^{1}$. This figure is greater than that for sawmill workers who also are involved in cutting wood; injury rates at sawmills are $171 \%$ higher than general industry ${ }^{1}$. The type of injuries sustained at wood pallet manufacturers and their rates of increase (1998-the last year this data was available) compared to general industry included amputations (1317\% higher), cuts and punctures (818\% higher), fractures (352\% higher), bruises (316\% higher) sprains and strains (194\% higher) and back pain (177\% higher) $)^{5}$.

In 2000, the wood pallet and skid industry (Standard Industrial Classification Code [SIC] code 2448) employed 46,500 workers $^{5}$. Our previous paper on the pallet manufacturing industry discussed noise exposure and ergonomic injury in the industry ${ }^{2}$. This current paper will provide an overview of measured exposures to airborne particulate and carbon monoxide in the wood pallet manufacturing industry, based on our observations and measurements at the visited companies.

Plants in the industry typically consisted of an area where wood was cut to sizes needed to make pallets, an area where the wood pieces were nailed together to make a pallet and another area where pallets were recycled (disassembled so damaged parts of the pallet could be removed). Although time weighted averages (TWAs) were not computed for exposures in these distinct areas, the spot measurements should serve as a guide to the industry processes that might be a source of excess exposure to workers. Few small business establishments provide on-site occupational health units, medical screening tests, pre-placement physicals, or employ or use industrial hygiene or safety personnel/ consultants ${ }^{6}$. As a consequence, prevention of occupational injury and illness is often difficult in small business establishments because they generally have few safety and health resources, do not hire staff devoted to safety and health activities, and often lack the ability to identify occupational hazards and conduct surveillance ${ }^{4,7}$. We believe that these measurements made in this study will be applicable to other pallet manufacturing operations because of the similarities of exposures-most plants cut wood and have at least one forklift.

\section{Methods}

Site visits were made to seven sites and researchers returned to four of those to take measurements for airborne wood dust, ventilation, and $\mathrm{CO}$. The sites were selected based on their proximity to the NIOSH location in Cincinnati, Ohio, the small size of the company ( $<50$ people), and their willingness to participate. The methods used to make the measurements were as follows:

Samples for CO were taken in the breathing zone of forklift drivers, in the general work areas, and approximately two feet above the exhaust of the forklifts for an average of 71 min (range 39-110). Measurements were made of exposures to 4 different drivers and at 4 workplaces. $\mathrm{CO}$ was measured in the fall; researchers returned to two plants in the winter to measure $\mathrm{CO}$ when the doors of the plants were closed. A Biosystems Toxi Ultra hand-held CO meter, which uses an electrochemical sensor that was calibrated in the NIOSH laboratory using a calibration constant of 50 parts per million (ppm) was used. This meter measured CO concentrations between 0 to $999 \mathrm{ppm}$ and was not designed to be placed in the exhaust stream.

Total airborne dust was measured using a real-time light scattering photometer (DataRAM, MIE, Inc., Billerica, MA $\left[\mathrm{LOD}=0.1 \mu \mathrm{g} / \mathrm{m}^{3} ;\right.$ range $=0.1 \mu \mathrm{g} / \mathrm{m}^{3}$ to $399.9 \mathrm{mg} / \mathrm{m}^{3}$, using multiple settings]). Short-term measurements of airborne dust were taken at several locations in the pallet manufacturing plants and were made by placing the instrument near equipment generating wood dust and as close to the position of the worker as possible. Data were collected for several minutes (range $1 \mathrm{~min} 10 \mathrm{~s}-6 \mathrm{~min} 50$ s, avg. 3 min $45 \mathrm{~s}$ ) at each machine. These data represent the dust emissions from each machine but may understate the total dust because of instrument bias toward the respirable range. It was not possible to make measures of these saws for $8 \mathrm{~h}$ because the measuring equipment would interfere with the operation of the equipment. Most importantly, these measurements were not taken as personal breathing zone samples from each worker and a TWA could not be generated for each measurement. The measures were only intended to identify areas and machinery for the plant owner with the potential for high levels of dust generation.

Table 1 Lists the Occupational Safety and Health Administration (OSHA) standards (Permissible Exposure Limits [PELs]), NIOSH guidelines (Recommended Exposure Limits [RELs]), and American Conference of Governmental Industrial Hygienists (ACGIH) Threshold Limit Values (TLVs) for wood dust and carbon monoxide that were analyzed in this study.

\section{Results}

\section{Measurements}

The following measurements were made during site visits and relate only to what was found at that pallet manufacturer on the day of our visit to the plant. These measurements were not 8-h samples and therefore are not assumed to be entirely representative of conditions at other times or at other pallet manufacturers. However, based on similar observations at several sites included in this study, it is reasonable that these measurements may serve as a guide for other pallet manufacturers. 
Table 1. Standards, Recommended Exposure Levels, and Guidelines

\begin{tabular}{|c|c|c|c|}
\hline $\begin{array}{c}\text { Chemical or } \\
\text { Physical Agent }\end{array}$ & OSHA PEL & NIOSH REL & ACGIH TLV \\
\hline Wood dust & $\begin{array}{l}15 \mathrm{mg} / \mathrm{m}^{3} \text { for total dust } 5 \mathrm{mg} / \mathrm{m}^{3} \text {, } \\
\text { for the respirable fraction of } \\
\text { that dust both as } 8-\mathrm{hWA}^{8)}\end{array}$ & $\begin{array}{c}1 \mathrm{mg} / \mathrm{m}^{3} \text { for all woods } 8 \text {-hTWA } \\
\text { Wood classified as a } \\
\text { potential occupational carcinogen }{ }^{9)}\end{array}$ & $\begin{array}{l}\text { Western red cedar } 0.5 \mathrm{mg} / \mathrm{m}^{3} \\
\text { All other species } 1 \mathrm{mg} / \mathrm{m}^{3}, \\
\text { both as } 8 \text {-h } \text { TWAs }^{10)}\end{array}$ \\
\hline $\mathrm{CO}$ & $50 \mathrm{ppm}$ as an 8-h TWA ${ }^{11)}$ & $\begin{array}{l}35 \mathrm{ppm} \text { as an } 8 \text {-h TWA with a } \\
\text { ceiling limit of } 200 \mathrm{ppm}^{12)} \\
\text { Immediately dangerous to life } \\
\text { and Health (IDLH)-1200 } \mathrm{ppm}^{13) *}\end{array}$ & $25 \mathrm{ppm}$ as an 8-h TWA \\
\hline
\end{tabular}

* The IDLH is the concentration that could result in death or irreversible health effects, or prevent escape from the contaminated environment within $30 \mathrm{~min}$.

\section{Carbon monoxide}

Each facility we visited used a forklift to transport wood to the assembly area or to pick up completed pallets. $\mathrm{CO}$ levels were measured at four plants that used either liquefied propane gas (LPG) or gasoline forklifts. The CO measurement results are presented in Table 2. Three of the four plants had levels of $\mathrm{CO}$ that would be below the 50 ppm PEL. Plant number 4 had levels of CO (109 ppm) that potentially exceeded both NIOSH recommendations ${ }^{10)}$ and OSHA standards. That plant used an LPG forklift. (See Table 3).
CO levels were measured in the back section of a trailer that was part of a tractor/trailer rig. CO levels increased up to $125 \mathrm{ppm}$ when a forklift entered the trailer, and returned to its original reading of $11 \mathrm{ppm}$ after approximately five minutes after the forklift left the trailer.

\section{Airborne dust concentration}

The pallet manufacturers we visited usually used hard wood, generally oak, to manufacture pallets. Hardwood dust is considered to be more toxic than softwood (i.e. pine) and more stringent exposure limits apply ${ }^{14)}$. The results of

Table 2. Co measurements (averages) at four wood pallet manufacturing plants

\begin{tabular}{|c|c|c|c|c|c|}
\hline Location of measurement & Plant & $\begin{array}{c}\text { Average } \\
\text { CO level ppm }\end{array}$ & Duration & $\begin{array}{l}\text { Ventilation } \\
\text { Status }\end{array}$ & Type of Forklift \\
\hline Approximately 1' above & 1 & 11.7 & $89 \mathrm{~min}$ & Door open & gasoline \\
\hline \multirow[t]{6}{*}{ exhaust pipe } & 2 & 12.0 & $42 \mathrm{~min}$ & Door open & LPG \\
\hline & 3 & 23.0 & $6 \mathrm{~min}$ & Door open & LPG \\
\hline & 4 & 109.0 & $78 \mathrm{~min}$ & Door closed & LPG \\
\hline & 4 & 69.0 & $101 \mathrm{~min}$ & Door open & LPG \\
\hline & 4 & 74.0 & $69 \min$ & Door closed and lift tuned up & LPG \\
\hline & 4 & 4.0 & $82 \mathrm{~min}$ & Door open & LPG (new forklift) \\
\hline Area sample-from main & 1 & 5.5 & $100 \mathrm{~min}$ & Door open & Gasoline \\
\hline \multirow[t]{6}{*}{ manufacturing area } & 2 & 2.8 & $48 \min$ & Door open & LPG \\
\hline & 3 & 9.0 & $39 \min$ & Door open & LPG \\
\hline & 4 & 109.0 & $75 \mathrm{~min}$. & Door closed & LPG \\
\hline & 4 & 35.0 & $55 \mathrm{~min}$ & Door open & LPG \\
\hline & 4 & 63.0 & $71 \mathrm{~min}$ & Door closed and lift tuned up & LPG \\
\hline & 4 & 2.0 & $83 \mathrm{~min}$ & Door open & LPG (new forklift) \\
\hline \multirow{8}{*}{$\begin{array}{l}\text { Personal breathing zone sample } \\
\text { (from forklift driver) }\end{array}$} & 1 & 6.2 & $110 \mathrm{~min}$ & Door open & Gasoline \\
\hline & 2 & 3.0 & $48 \min$ & Door open & LPG \\
\hline & 3 & 3.3 & $79 \mathrm{~min}$ & Door open & LPG \\
\hline & 4 & 67.0 & $80 \mathrm{~min}$ & Door closed & LPG \\
\hline & 4 & 50.0 & $97 \mathrm{~min}$ & Door open & LPG \\
\hline & 4 & 53.0 & $80 \mathrm{~min}$ & Door closed and lift tuned up & LPG \\
\hline & 4 & 40 & $74 \mathrm{~min}$ & Sample on trailer & LPG \\
\hline & 4 & 2.0 & $84 \mathrm{~min}$ & Door open & LPG (new forklift) \\
\hline
\end{tabular}


Table 3. DataRAM measurements of dust in a pallet plant

\begin{tabular}{ccccc}
\hline $\begin{array}{c}\text { Measurement } \\
\text { Location }\end{array}$ & $\begin{array}{c}\text { Minimum } \\
\text { Concentration } \\
\left(\mathrm{mg} / \mathrm{m}^{3}\right)\end{array}$ & $\begin{array}{c}\text { Maximum } \\
\text { Concentration } \\
\left(\mathrm{mg} / \mathrm{m}^{3}\right)\end{array}$ & $\begin{array}{c}\text { Average } \\
\text { Concentration } \\
\left(\mathrm{mg} / \mathrm{m}^{3}\right)\end{array}$ & Duration \\
\hline Resaw & 0.48 & 1.29 & 0.86 & $3 \mathrm{~min}$ \\
Cut off saw \#1 & 0.36 & 2.22 & 0.87 & $4 \mathrm{~min} 30 \mathrm{~s}$ \\
Radial arm saw & 0.48 & 9.30 & 1.45 & $3 \mathrm{~min} 20 \mathrm{~s}$ \\
Cut off saw \#2 & 0.59 & 4.40 & 1.40 & $6 \mathrm{~min} 50 \mathrm{~s}$ \\
$\quad$ Notcher & 1.28 & 2.05 & 1.67 & $1 \mathrm{~min} 10 \mathrm{~s}$ \\
\hline
\end{tabular}

dust measurements from one plant are presented in Table 3. Measurements were made next to operating saws and, although all dust was measured, most dust was wood dust created by the saw.

Proper dust control is incumbent on the ventilation system being turned on and functioning properly. During the site visits, two employees reported that in some cases the ventilation system was not turned on and employees operated the saws with no ventilation.

During field visits, poor housekeeping practices were often noted. Piles of wood dust were visible that could become airborne if disturbed. Dust was occasionally noted collecting around leaks in exhaust ducts. The floors at most facilities were covered with dust making them slippery, creating a fall and fire hazard. Woodworking facilities are especially at risk for fire since sawdust will ignite and burn far more readily than whole pieces of lumber.

\section{Discussion and Interventions}

Using short term sampling allowed us to quickly identify areas of potentially high exposure and identify areas requiring intervention. In the case of $\mathrm{CO}$ we saw the effects of a malfunctioning forklift on area and personal breathing zone samples. For ventilation and wood dust, we demonstrated that saws in operational pallet making facilities can make a substantial amount of dust and confirmed the need for proper ventilation both for the plant owner and the employees.

\section{Carbon monoxide}

Gasoline powered forklifts usually produce the highest amounts of $\mathrm{CO}$ but propane powered forklifts may also emit substantial amounts of $\mathrm{CO}$, particularly if a forklift is not properly maintained. A CO emissions test is needed to measure the amount of $\mathrm{CO}$ being emitted by a forklift in order to properly adjust the forklift. In any case, a poorly maintained propane powered forklift may generate more $\mathrm{CO}$ than a well maintained gasoline engine ${ }^{15)}$. Regulations for $\mathrm{CO}$ emissions may be found in Table 1 .

Levels of $\mathrm{CO}$ were elevated at plant \#4, both for the operator of the forklift itself, and for the employees on the plant floor. In this plant, the increased levels were due to a forklift generating too much CO. Although ventilation was poor in most plants, exhaust emission (109 ppm) and operator exposure $(67 \mathrm{ppm})$ to $\mathrm{CO}$ at this plant were far greater than any other plant. It is unlikely that any reasonably increased ventilation rate would be able to completely ameliorate the increased exposure; a properly adjusted forklift without adequate ventilation can produce $\mathrm{CO}$ levels that can cause CO poisoning ${ }^{16}$.

Numerous reasons were hypothesized for the increased $\mathrm{CO}$ in plant \#4. The first was that the forklift was improperly adjusted since no emission test was performed on the forklift. The second possible reason for the increased CO levels in plant \#4 was the closing of outside doors due to cooler weather combined with the lack of mechanical ventilation in the building. The third possibility was that there was a mechanical defect in the forklift resulting in higher $\mathrm{CO}$ emissions.

All three possibilities occurred at Plant \#4. No CO emissions test was performed. When it was, it was found that the main problem resulting in increased $\mathrm{CO}$ emissions was that the forklift was improperly adjusted because of a mechanical flaw. Closing the doors of the plant in winter exacerbated the effect of this flaw and resulted in even higher CO levels to workers. When a new forklift was purchased at plant \#4, CO levels dropped dramatically to $2 \mathrm{ppm}$ as measured when the door to the plant was open.

\section{Airborne Dust Concentration}

Airborne dust was measured near the machine generating that dust when the machine was in operation; measurements in this study were, therefore, taken over very short time periods. Machines were constantly used, and it would have been difficult to place the instrument such that it would not interfere with the operator and still collect a meaningful 8$\mathrm{h}$ sample. The measurements, therefore, are a worst-case scenario and should not be taken as an 8-h TWA. These data are not representative of full shift exposures, but only provide some insight into the magnitude of short term dust exposure at various machines and guide the selection of machines for future sampling. Long term, full-shift personal samples are needed to make an assessment of actual operator exposure to airborne dust in pallet shops.

Dust created by sawing and other woodworking processes can be hazardous. ACGIH considers hardwood wood dust to be a "confirmed" carcinogen ${ }^{10}$. It is strongly linked to nasal cancer and has been suggested as a link in cancer of the oropharynx, lung, lymphatic system, stomach, and colon $^{14)}$. Wood dust may be deposited in the nose and the lower airways. Many of the wood particles generated by the wood pallet industry are greater than 5 microns and are deposited in the nose, while some particles are in the size 
0.5 to $5 \mu \mathrm{m}$, are respirable, and are deposited in the lower airways $^{17)}$.

Exposure to wood dust has long been associated with a variety of adverse health effects. Besides hardwood dust being a potential carcinogen, wood dust exposure may also result in dermatitis, allergic respiratory effects, and mucosal and non-allergic respiratory effects ${ }^{18)}$. Contact with the irritant compounds in wood sap can cause dermatitis and other allergic reactions. Respiratory effects of wood dust exposure include asthma, eye irritation, nasal dryness and obstruction, prolonged colds, and frequent headaches ${ }^{14)}$. Fine sawdust also makes an excellent medium for mold growth ${ }^{19)}$.

There is currently no OSHA PEL for wood dust; but it is controlled as particulate not otherwise regulated (PNOR) or nuisance dust (See Table 1). The PEL for PNOR is 15 $\mathrm{mg} / \mathrm{m}^{3}$ for total dust and $5 \mathrm{mg} / \mathrm{m}^{3}$, for the respirable fraction of that dust, both as 8-h TWAs. Both NIOSH and the ACGIH, however, have recommendations for wood dust exposure, and NIOSH classifies wood dust as a potential occupational carcinogen. OSHA strongly encourages employers to keep exposures to a minimum and to adopt the ACGIH levels ${ }^{18)}$.

Dust collection is best accomplished at the source-at the point of generation, if feasible, and all of these machines measured had some form of local exhaust ventilation except for cut off saw \#1. For many pieces of equipment, welldesigned local exhaust ventilation and exhaust hoods can collect most of the dust generated before it reaches the operator. Despite the local exhaust ventilation, three of the five saws had short term average wood dust concentrations that would possibly be above the NIOSH REL and ACGIH TLV of $1 \mathrm{mg} / \mathrm{m}^{3}$ if the same exposure lasted for $8 \mathrm{~h}$. Based on our limited measurements, none of the measured dust concentrations would be above the OSHA PEL of $15 \mathrm{mg} / \mathrm{m}^{3}$.

\section{Conclusions}

Based on measurements, site visits and interviews, potential occupational safety and health hazards were apparent from this study of the pallet industry. These hazards included excessive exposure to $\mathrm{CO}$ due to an older, defective forklift and wood dust exposure resulting from insufficient or improper exhaust ventilation for the saws. The purpose of these measurements was to identify certain practices and procedures that might result in excessive exposure to employees. These measurements can serve as a guide for the individual employers to start further, and more detailed, measurement that are specific for the plant being studied. In particular, these task-based exposure assessments can help to inform owners and managers of small pallet manufacturing businesses of control-focused strategies to address the most immediate hazards. This type of semi-quantitative risk assessment and management approach, resembling control banding, is more readily adopted for use in this and similar industries, given limited resources for occupational hygiene sampling and exposure assessment.

NIOSH is preparing an educational document for owners and managers engaged in the wood pallet manufacturing industry. This document will include more detailed recommendations and workplace solutions as well as recommendations for workforce education.

\section{Disclaimer}

The findings and conclusions in this report are those of the author(s) and do not necessarily represent the views of the National Institute for Occupational Safety and Health.

\section{References}

1) Bureau of Labor Statistics (2003) Incidence rates of nonfatal occupational injuries and illnesses by industry and selected case types, 2000. Available at http:// www.bls.gov/iif/oshwc/osh/os/ostb1001.txt (Accessed November 5, 2003).

2) Malkin R, Hudock SD, Hayden C, Lentz TJ, Topmiller J, Niemeier RW (2005) An assessment of occupational safety and health hazards in selected small businesses manufacturing wood pallets_-part 1 . Noise and physical hazards. J Occup Environ Hyg 2, D18-21.

3) US Department of Commerce (2001) US Census Bureau, Economics and Statistics Bureau, County Business Patterns 1998, CD-ROM. US Department of Commerce, Washington, DC.

4) Lentz TJ, Okun A, Schulte P, Stayner L (1999) Identifying High-Risk Small Business Industries: The Basis for Preventing Occupational Injury, Illness, and Fatality. DHHS (NIOSH) Publication No. 99-107. NIOSH, Cincinnati.

5) Bureau of Labor Statistics (2003) Incidence rates(1) for nonfatal occupational injuries and illnesses involving days away from work(2) per 10,000 full-time workers by industry and selected natures of injury or illness, 1998. Available at http://www.bls.gov/iif/oshwc/osh/case/ ostb0796.txt (Accessed November 17, 2003).

6) Lentz TJ, Sieber WK, Jones JH, Piacitelli GM, Catlett LR (2001) Surveillance of safety and health programs and needs in small U.S. businesses. Appl Occup Environ Hyg J 16, 1016-21.

7) Okun A, Lentz TJ, Schulte P, Stayner L (2001) Identifying high-risk small business industries for occupational safety and health interventions. Am J Ind Med, 39, 301-11.

8) OSHA Regulations (Standards - 29 CFR) (1992) TABLE Z-1 Limits for Air Contaminants. - 1910.1000 TABLE Z-1. Available at http://www.osha.gov/pls/oshaweb/ owadisp.show_document?p_table=STANDARDS\&p_id=9992 (Accessed November 7, 2003).

9) NIOSH (2003) NIOSH Pocket Guide to Chemical Hazards —Wood dust. Available at http://www.cdc.gov/niosh/npg/ npgd0667.html (Accessed November 14, 2003). 
10) American Conference of Governmental Industrial Hygienists (2005) TLVs and BEIs. 59, ACGIH ${ }^{\circledR}$, Cincinnati.

11) Department of Labor, Occupational Safety and Health Administration (2003) Carbon Monoxide. US Department of Labor. Occupational Safety and Health Administration, Washington DC. Available at http://osha.gov/pls/oshaweb/ owadisp.show_document?p_table=STANDARDS\&p_id =10366\&p_text_version=FALSE (Accessed May 9, 2003).

12) NIOSH (1996) Preventing Carbon Monoxide Poisoning from Small Gasoline-Powered Engines and Tools, DHHS (NIOSH) Publication No. 96-118. NIOSH, Cincinnati.

13) NIOSH (2003) NIOSH pocket guide to chemical hazards. Available at http://www.cdc.gov/niosh/npg/npg.html (Accessed January 30, 2003).

14) Dement J (2001) Wood Dust. In: Patty's Toxicology. eds. by Bingham E, Cohrssen B and Powell C, 628-47. John Wiley and Sons, New York.
15) Michigan Department of Public Health (1966) Michigan's Occupational Health. The industrial lift truck/Help mate or occupational hazard? Michigan Department of Public Health 12, 6-8.

16) Fawcett TA, Moon R, Fracica P, Mebane G, Theil D, Piantodosi C (1992) Warehouse workers' headache. Carbon monoxide poisoning from propane-fueled forklifts. JOEM 34, 12-5.

17) US Department of Health and Human Services, Public Health Service (2000) National Toxicology Program. 10th report on carcinogens. US Department of Health and Human Services, Washington DC.

18) OSHA (2003) Woodworking e-tool. Available at http:// www.osha.gov/SLTC/etools/woodworking/health_ wooddust.html. (Accessed February 10, 2003).

19) Eduard W, Sandven P, Levy F (1993) Serum Ig G antibodies to mold spores in two norwegian sawmill populations: relationship to respiratory and other work-related symptoms. Am J Ind Med 24, 207-22. 